\title{
Closing the Deal: Making the Right Congressional Decision About Patent SETTLEMENT AGREEMENTS
}

\author{
Amy C. Waltz
}

\section{TABLE OF CONTENTS}

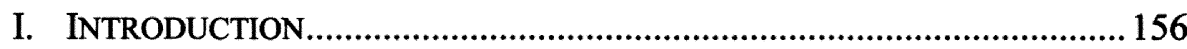

II. RELEVANT LAW: INCENTIVES TO SETTLE PATENT

INFRINGEMENT SUITS BY AGREEMENT

A. Patent Law: Conflicting Interests Give Rise to

Incentives to Settle.

B. The Sherman Antitrust Act: Protecting Competition................. 160

C. The Complete Process: From ANDA to Settlement.................... 161

D. Today's Pharmaceutical Market: Market Incentives to Settle Patent Infringement Suits .......................................... 162

III. THE HISTORY OF THE DEBATE ...................................................... 164

A. Schering-Plough: Patent Settlement Agreements with Upsher and ESI.

B. Zeneca: Patent Settlement Agreement with Barr...................... 166

C. Bayer: Patent Settlement Agreement with Barr ....................... 167

IV. THE DETAILS OF THE DEBATE ...................................................... 168

A. The Arguments for Settlement: The Courts and the Industry

1. The Courts' Reasoning: Consistently Upholding

Settlement Agreements

2. The Pharmaceutical Industry: Protecting Investments

Through Settlement.

3. The View of the Generic Manufacturers: $A$ Good

Business Decision.

B. The Arguments Against Patent Settlement Agreements:

The FTC and the Consumer.

1. The FTC: Protecting the Consumer............................... 173

2. Consumer Groups and Other Interested Parties................. 175

V. MAKING THE CALL: THE BEST OPTION FOR CONGRESS ....................... 176

A. The Call for Congressional Action........................................ 176

$B$. Congress' Options: Codification, Legislation, and Limitation

* J.D. Candidate, 2008, Indiana University School of Law-Indianapolis; B.A., 2005, Franklin College of Indiana. 
C. The Right Choice: Codification, with Limits........................... 179

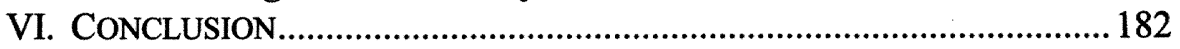

\section{INTRODUCTION}

In an era of rapidly rising health care costs, America's legislators are continually searching for ways to decrease costs to the consumer, while America's health care suppliers and providers strive to increase profits and improve the bottom line. Recently, these two competing interests have come head to head in one of health care's largest economic arenas, the pharmaceutical market. To date, the skirmishes have taken place in courts, but the biggest battle is still to come, on the floors of the United States Congress.

One current battle has centered on patent settlement agreements made between brand name pharmaceutical manufacturers (often referred to collectively as Big Pharma) and generic manufacturers. Recently brought to the forefront of health care law by major pharmaceutical companies such as Schering-Plough ("Schering") and Bristol-Myers Squibb, these settlements have been the subject of many recent court cases and congressional hearings. The agreements are aimed at avoiding patent litigation and often include provisions which prevent the generic version of the pioneer drug from entering the market for a certain period of time. The Federal Trade Commission ("FTC") claims that these agreements are resulting in unsubstantiated higher pharmaceutical costs, and that they may have anticompetitive effects on the market.

After the Supreme Court's recent denial of certiorari in two major patent settlement agreement cases, ${ }^{1}$ the FTC has turned to Congress for relief, seeking legislation that would prohibit or, in the very least, limit these settlements. Congress began holding hearings on the issue in the summer of 2006 and has continued to hear testimony on the issue as recently as January, 2007. The question in the minds of all involved is simple: Should Congress address the issue of the validity of patent settlement agreements, or is this an issue for the courts to decide?

First, this Note discusses the arguments on both sides of the issue and will analyze the options available to Congress in light of the Supreme Court's refusal to hear the cases. Initially, the discussion identifies relevant patent and antitrust law, the current state of the pharmaceutical industry, and the effect each has on incentives for pharmaceutical companies to settle patent infringement suits. Second, this Note addresses the history of the debate, chronicling the three major court cases involving these agreements. Third, this Note details the arguments being made by the major players involved. These players include the pharmaceutical industry, the courts, the FTC, and consumer groups which have weighed in on the topic. Forth and finally, the discussion analyzes 
the various options available to Congress and suggests that Congress should codify the courts' position while incorporating provisions to address the FTC's concern with anticompetitive effects.

\section{RELEVANT LAW: INCENTIVES TO SETTLE PATENT INFRINGEMENT SUTTS BY AGREEMENT}

In the pharmaceutical industry, patent infringement suits are common and can be time-consuming and costly for both parties. Generic manufacturers have very little to lose from challenging pioneer patents in an attempt to gain a finding of invalidity. Winning a patent infringement suit against a blockbuster drug can earn a generic company millions of dollars in profits. ${ }^{2}$ On the other hand, pioneer patent holders have everything to lose. Indeed, if the pioneer patent holder's patent is found to be invalid, a brand name pharmaceutical manufacturer is unlikely recoup the profits lost in the years of research and development it has devoted to development of the drug. As such, pioneer patent holders have huge incentives to fight patent infringement suits with every available resource.

Recently, many pharmaceutical companies, both brand name and generic, have found settlement of such suits to be extremely advantageous. Patent and antitrust laws, while designed to promote competition, serve conflicting interests which can give rise to incentives to settle. Issues within the pharmaceutical industry may provide additional incentives. For example, litigation costs for both sides are slashed when settlements are made early in the process, and in many situations, generic companies gain licenses to market drugs which would not otherwise be available to them and vice versa. These incentives have made settlement of patent infringement suits increasingly popular.

Most settlements include payments to the generic manufacturer in return for a delay in the market entry of the generic drug. These payments are often referred to as brand payments ${ }^{3}$ or reverse payments by the courts because, as the Second Circuit describes, the valid patent holder has the right to exclude the infringer from the market but "nonetheless pays that party not to do so."

2. Blockbuster drugs are generally defined as drugs with more than one billion dollars per year in sales. MARCIA ANGELL, THE TRUTH ABOUT THE DRUg COMPANIES: How THEY Deceive Us and What to Do ABout It 10 (Random House Trade Paperbacks 2005). Some industry members, however, use $\$ 500$ million as the threshold for classifying blockbuster drugs. See generally Generic Pharmaceuticals: Marketplace Access and Consumer Issues: Hearing before the S. Comm. on Commerce, Science, and Transportation, 107th Cong. 13 (2002) (statement of Kathleen D. Jaeger, President \& CEO, Generic Pharm. Ass'n), available at http://frwebgate.access.gpo.gov/cgi-bin/getdoc.cgi?dbname $=107$ senate_hearings\&docid=f:9 0155.pdf.

3. John Fazzio, Pharmaceutical Patent Settlements: Fault Lines at the Intersection of Intellectual Property and Antitrust Law Require a Return to the Rule of Reason, $11 \mathrm{~J}$. TECH. L. \& POL'Y 1, 14 (2006).

4. Joblove v. Barr Labs, Inc. (In re Tamoxifen Citrate Antitrust Litig.), 466 F.3d 187, 205 (2d Cir. 2006), cert. denied, 127 S. Ct. 3001 (2007) (While the official name of the case 
some cases, called supply agreements, the brand name manufacturer may also receive licenses to market similar or other drugs made by the generic manufacturer under the name of the brand name. ${ }^{5}$ For example, in a much-litigated settlement between pharmaceutical manufacturer Schering and generic manufacturer Upsher-Smith Laboratories ("Upsher"), Schering received several licenses to market Upsher products. ${ }^{6}$ The opposite may also be true. Under license agreements, the generic company may receive non-exclusionary licenses to market generic versions of the pioneer drug before or after expiration of the pioneer patent. $^{7}$

The FTC, fearing that these patent settlement agreements are causing pharmaceutical costs to rise, has repeatedly challenged the settlements, imploring courts to find that such settlements violate antitrust law. Despite conflicting standards of review for cases challenging patent settlement agreements, ${ }^{8}$ however, courts have generally found settlement agreements to be valid as long as (1) the infringement claim is "neither a sham nor otherwise baseless," and (2) the settlement does not "[restrain] competition beyond the scope of the . . . [p]atent."

\section{A. Patent Law: Conflicting Interests Give Rise to Incentives to Settle}

Patent protection has been a tenet of American law since the writing of the Constitution. The framers themselves envisioned patent protection for innovation, establishing a specific right of Congress " $[t]$ o promote the progress of science and useful arts, by securing for limited times to authors and inventors the exclusive right to their respective writings and discoveries; ..."11 Today's patent laws generally allow twenty years of patent protection for pharmaceutical discoveries. ${ }^{12}$ The effective life of such patents is, however, often much shorter. Companies routinely file patent applications early in the drug development process to better protect their research investment as it moves through the drug approval process. By the time the drug is approved by the Food and Drug Administration ("FDA") and reaches the market, half of the patent term may have expired.

is Joblove, the case will be referred to as Tamoxifen for clarity purposes throughout the text of this Note. References to the actual drug at issue will be lower-case ("tamoxifen")).

5. Fazzio, supra note 3, at 13.

6. Schering-Plough Corp. v. FTC, 402 F.3d 1056, 1059-60 (11th Cir. 2005), cert. denied, 126 S.Ct. 2929 (U.S. June 16, 2006); see also discussion infra Part II.A.

7. Fazzio, supra note 3, at 13.

8. For further discussion on the relevant standard of review, see Fazzio, supra note 3, at 38 (suggesting that the Supreme Court should adopt a "rule of reason" analysis).

9. Joblove, 466 F.3d at 208.

10. In re Ciprofloxacin Hydrocloride Antitrust Litig., 363 F. Supp. 2d 514, 540

(E.D.N.Y. 2005).

11. U.S. CONST. art I. $\S 8$, cl. 8 .

12. 35 U.S.C.A. $\S 154(a)(2)$ (West 2007). 
Pharmaceutical patent challenges by generic competitors are regulated by the Hatch-Waxman Amendments ("Amendments"). ${ }^{13}$ The Amendments propose to "balance two conflicting policy objectives: to induce name-brand pharmaceutical firms to make the investments necessary to research and develop new drug products, while simultaneously enabling competitors to bring cheaper, generic copies of those drugs to market." ${ }^{\text {"14 }}$ In attempting to balance these conflicting interests, the Amendments create a complex system in which generic manufacturers may produce and market copies of pioneer drugs in certain situations. Often, the conflicting interests served by the Amendments provide incentives for pioneer patent holders and generic manufacturers to settle patent infringement suits.

Once a pioneer drug has been patented and approved by the FDA, the Amendments allow generic manufacturers to file an Abbreviated New Drug Application ("ANDA"). The ANDA must state that the drug is "bioequivalent" to the pioneer drug and certify that generic marketing of the drug will not infringe on the pioneer patent for one of four reasons: First, the ANDA application may certify that the pioneer patent has not been filed. Second, the ANDA application may certify that the pioneer patent is expired. Third, the ANDA application may certify that the pioneer patent will expire on a certain date. Fourth, the ANDA application may certify that the pioneer patent is invalid or not infringed upon by the proposed generic. ${ }^{15}$ This last certification is the most common and the most relevant to the subject of patent agreements. Under this certification, commonly known as a Paragraph IV certification, "the ANDA [filer] must give notice to the pioneer patent holder ... [after which the] patent holder has forty-five days within which to file suit against the generic manufacturer. Filing the suit triggers an automatic 30-month stay during which the FDA cannot approve the generic manufacturer's ANDA."16

In essence, the thirty-month stay gives the pioneer manufacturer an extra two and one-half years of exclusivity on the market, precluding any issues of infringement damages since the generic drug cannot be marketed until the end of the thirty-month period. The thirty-month stay also provides time for the patent litigation to commence and conclude. ${ }^{17}$ If the generic company wins, and the court finds the patent to be invalid or not infringed, the generic is able to enter the market immediately following the thirty-month period. If the brand name manufacturer wins and the patent is held to be valid, however, the generic is precluded from marketing its own version of the drug until expiration of the pioneer patent.

13. Drug Price Competition and Patent Restoration (Hatch-Waxman) Act of 1984, 98 Stat. 1585 (1984) (codified as amended at 21 U.S.C.A. $\$ 355$ (West 2007)).

14. M. Elaine Johnston \& Matthew J. Galvin, Antitrust Aspects of Settling Intellectual Property Litigation, 867 PLI/PAT 159, 162 (2006) (quoting H.R. Rep. No. 98-957 at 14).

15. Id.

16. Id. at 162-63. See the same article for more detailed information regarding the ANDA process.

17. ANGELL, supra note 2 , at 180. 
As additional incentive for generic manufacturers to file ANDAs, the first company to file such an application without infringing upon the pioneer patent receives a 180 -day period of exclusive marketing rights. ${ }^{18}$ While the 180 -day exclusivity period effectively excludes other generic manufactures from marketing their own generic versions of the pioneer drug once the pioneer patent has been eliminated, it also creates the opportunity for a bottleneck. ${ }^{19}$ If the first ANDA filer fails to market its generic drug and fails to trigger the exclusivity period, all other generic manufacturers are precluded from entering the market as well. ${ }^{20}$ Therefore, "if the brand name manufacturer can reach a settlement agreement, convincing the first ANDA filer not to enter the market, he prevents all generic entry."21 Thus, the exclusivity period provided by the Amendments gives brand name manufacturers some incentive to settle patent infringement claims with generic manufacturers, effectively prolonging the bottleneck effect.

The Medicare Prescription Drug, Improvement, and Modernization Act of 2003 ("Medicare Act") modified the Amendments, clarifying much-litigated issues. $^{22}$ First, the Medicare Act allows two generic applicants to share the 180-day exclusivity period, in the event that both manufacturers file ANDA applications on the same day. ${ }^{23}$ Second, in order to reduce the bottleneck effect created by the 180-day exclusivity period, the Medicare Act states that the exclusivity period is forfeited if the generic filer does not meet certain time restrictions for marketing its generic version of the pioneer drug. ${ }^{24}$ Thus, the Medicare Act reduces the incentives to settle patent infringement claims provided by the Amendments by allowing other generic manufactures to gain subsequent exclusivity periods if the original generic filer does not market its version of the drug.

Additionally, the Medicare Act may impose a chilling effect on this activity by requiring all patent settlements be reported to the FTC. ${ }^{25}$ Thus, one effect of entering into a patent settlement agreement is to trigger FTC notice and review.

\section{B. The Sherman Antitrust Act: Protecting Competition}

The Sherman Antitrust Act ("Sherman Act") prohibits "[e]very contract, combination in the form of trust or otherwise, or conspiracy, in restraint of trade

18. Johnston \& Galvin, supra note 14 , at 163.

19. Fazzio, supra note 3, at 12.

20. Id.

21. Id.

22. Medicare Prescription Drug, Improvement, and Modernization (Medicare Act) Act of 2003, tit. XI, 117 Stat. 2066 (2003) (codified as amended in scattered sections of 21

U.S.C.A. § 355 (West 2007)).

23. Fazzio, supra note 3 , at 17.

24. Medicare Act, tit. XI $\S 1102$ (codified as amended at 21 U.S.C.A $\S$ $355(\mathrm{j})(5)(\mathrm{D})(\mathrm{ii}))$.

25. Id. 
or commerce. ..."26 The Act's primary purpose "is to protect interbrand competition. ... [which] takes place when manufacturers of the same product compete for the business of consumers, creating lower prices."27 Settlement agreements between brand name pharmaceutical companies and generic manufacturers are an example of interbrand competition and fall under the Sherman Act. $^{28}$ Opponents of patent settlement agreements argue that the settlements violate the purpose of the Sherman Act by discouraging interbrand competition and keeping pharmaceutical costs to consumers artificially high. ${ }^{29}$

\section{The Complete Process: From ANDA to Settlement}

Due to the complexity of the interactions between the Amendments, the Medicare Act, and the Sherman Act, it may be helpful to consider an example of the complete process, using the Schering and Upsher settlement as an example. All other settlements discussed in this Note took place under similar circumstances and in a similar fashion.

Schering owned the patent for the blood pressure medication K-Dur 20 and its extended-release coating. The patent was scheduled to expire September 5, 2006. ${ }^{30}$ In 1995, Upsher filed a Paragraph IV ANDA with the FDA, claiming that Schering's patent was either invalid or would not be infringed by Upsher's generic version. ${ }^{31}$ Schering promptly filed a patent infringement suit against Upsher, triggering the thirty-month stay provided by the Amendments. ${ }^{32}$

If a trial had taken place and if the court had found that Schering's patent was either invalid or not infringed upon, Upsher would have been able to market its generic version immediately. In addition, Upsher would have enjoyed the 180-day exclusivity period, during which no other generic version of K-Dur 20 could be marketed. If, on the other hand, a court had found Schering's KDur 20 patent to be valid, Upsher would have been excluded from the market until the expiration of the patent in 2005 .

A court was never given the opportunity to decide the validity of the $\mathrm{K}$ Dur 20 patent. In 1997, prior to trial, Schering and Upsher were able to reach a settlement agreement, which included the sharing of licenses between the companies and the payment of royalty fees from Schering to Upsher. ${ }^{33}$ The companies agreed to delay Upsher's entry into the market until September 1, 2001, nearly five years before expiration of the Schering patent. ${ }^{34}$

26. Sherman Act, 15 U.S.C.A $\S 1$ (West 2007).

27. Fazzio, supra note 3 , at 24.

28. See Fazzio, supra note 3, at 23-28.

29. See infra Part IV.B.

30. Schering-Plough Corp. v. FTC, 402 F.3d 1056, 1058 (11th Cir. 2005), cert. denied, 126 S.Ct. 2929 (U.S. June 16, 2006).

31. Id. at 1058-59.

32. Id. at 1059 .

33. Id at 1059-60.

34. Id. at 1059. 
In March, 2001, the FTC filed suit against Schering, Upsher, and a third generic company which had also settled with Schering, claiming that the two patent settlement agreements violated the Sherman Act because they prevented interbrand competition. ${ }^{35}$ An Administrative Law Judge found against the FTC, as did the Eleventh Circuit. ${ }^{36}$ The Supreme Court denied certiorari in July, 2006. ${ }^{37}$

As suggested, the patent exclusivity and market entry process can be extremely complex. For the purposes of this Note, however, specific information about the patents involved will be irrelevant. Only the facts of the three litigated settlement agreements discussed below will be considered, as they are best representative of the current debate. ${ }^{38}$ These courts have chosen a factspecific inquiry into the validity of patent settlement agreements, focusing generally on the anticompetitive effects of the settlements.

\section{Today's Pharmaceutical Market: Market Incentives to Settle Patent Infringement Suits}

According to the Centers for Medicare and Medicaid Services, Americans will spend $\$ 2,394$ billion on health care in $2008 .{ }^{39}$ Of that amount, $\$ 247$ billion will be spent on prescription drugs alone, making the pharmaceutical industry one of the most profitable industries in America. ${ }^{40}$ In this highly competitive market, however, profits are often not realized for years. The new drug development process is both costly and time-consuming and, as such, pharmaceutical companies carefully consider all new drug research and are always searching for new ways to protect their investments. According to the Pharmaceutical Research and Manufacturers of America ("PhRMA"), a public policy advocacy group comprised of America's largest pharmaceutical companies, "[o]nly one of every 10,000 potential medicines investigated by America's research-based pharmaceutical companies makes it through the research and development pipeline" and is approved by the FDA. ${ }^{41}$ In addition, PhRMA contends that gaining approval for a single drug and getting that drug to market

35. Id. at 1061 .

36. Id. at $1061,1076$.

37. Schering-Plough Corp. v. F.T.C., 126 S.Ct. 2929 (U.S. June 16, 2006). For more details regarding the Schering settlement agreements, see infra Part III.A.

38. Schering-Plough Corp., 402 F.3d 1056 at1058; Joblove v. Barr Labs, Inc. (In re Tamoxifen Citrate Antitrust Litig.), 466 F.3d 187, 193-94 (2d Cir. 2006) cert. denied, 127 S. Ct. 3001 (2007); In re Ciprofloxacin Hydrocloride Antitrust Litig., 363 F. Supp. 2d 514 (E.D.N.Y. 2005). See also infra Part III.

39. U.S. DEPT. OF HEALTH \& HuMAN SERVICES, CTR's FOR MEDICARE \& MEDICAID SERV'S, HEALTH CARE EXPENDITURES PROJECTIONS: 2007-2017, tbl. 1, available at http://www.cms.hhs. gov/NationalHealthExpendData/Downloads/proj2007.pdf.

40. Id. at tbl. 2 .

41. PhRMA, Innovation, http://www.phrma.org/innovation (last visited Mar. 15, 2008 ). 
can take an average of fifteen years of research and development and can cost over $\$ 800$ million. ${ }^{42}$

Critics of the pharmaceutical industry dispute these figures, which the industry often uses to explain the high cost of pharmaceutical drugs. For example, Marcia Angell, former editor-in-chief of The New England Journal of Medicine, criticizes the industry figure, which was developed by the Tufts Center for the Study of Drug Development in 2001, as being impractically high due to problems with the Center's calculations. ${ }^{43}$ She alleges that the real cost is closer to $\$ 265$ million per drug, almost a quarter of the total estimated by the industry. ${ }^{44}$ In an industry which is particularly secretive regarding the intricate details of its research and development information, Angell used market information to determine her own figures, simply dividing the amount of money spent by the industry on research and development in 2000 by the total number of new drugs introduced to the market that year. ${ }^{45}$ Angell's formula, however, fails to consider that the cost of drugs which make it to the market must also include the costs of researching those drugs and biological compounds which fail to reach the market or are abandoned even before reaching the FDA approval process. Indeed, due to the nature of the industry, each drug which reaches the market must help recoup costs spent on research and development of both future drugs and failed drugs.

Further clarification of which figure is closer to the actual research and development cost of pharmaceuticals is better left to economists; however, it is clear from either figure that pharmaceuticals are a costly investment. As such, pharmaceutical companies spend millions each year attempting to protect and extend patents. According to Angell, increasing efforts by pharmaceutical companies and changes in patent law have extended the effective patent life of brand name pharmaceuticals by six years since $1980 .^{46}$

Patent settlement agreements are becoming an increasingly popular form of protection for research and development investments. In 2005 alone, eleven patent settlement agreements were made between brand name and generic manufacturers. ${ }^{47}$ Of those, three included reverse payments to the generic manufacturer in order to restrict the generic version's market entry, one restricted the generic's market entry with no compensation, and seven included no restrictions on market entry whatsoever. ${ }^{48}$ The current debate revolves largely around the first type of agreement, where generic manufacturers agree to

42. Id.

43. ANGELL, supra note 2, at 41-46.

44. Id. at 40 .

45. Id. at 39 .

46. Id. at 10 .

47. Bureau of Competition, Fed. Trade Comm'n, Agreements Filed With the FEDERAL TRADE COMMISSION UNDER THE MEDICARE PRESCRIPTION DRUG, IMPROVEMENT, AND MODERNIZATION ACT OF 2003: SUMMARY OF AGREEMENTS FILED IN FY 2005, 1 (2006), available $a t$ http://www.ftc.gov/os/2006/04/fy2005drugsettlementspt.pdf.

48. Id. at 3-6. 
delay market entry of their generic versions in return for some type of compensation, often in the form of reverse payments.

Incentives for brand name manufacturers to settle patent infringement suits against generic manufacturers are high. Prices of brand name drugs can fall as much as twenty percent once a generic enters the market, ${ }^{49}$ and "[a]s governments and regulators struggle to reduce the drugs bill for an ageing [sic] population, patients are being moved on to generics [sic] drugs faster than before. ..."50 Increasingly, out of court settlements are becoming a cheaper and more efficient way of defending pharmaceutical patents challenged by generic manufacturers, and "[S]ome drug giants [even] regard settlements as a way to bribe a generics firm to delay its introduction of a cut-price product. American antitrust officials worry this is to the detriment of the consumer." 51 The FTC has resolutely challenged these settlements and today's pharmaceutical executives understand that such settlements need to be consumer-friendly in order to be approved by attorneys general and the FTC. ${ }^{52}$

\section{THE HISTORY OF THE DEBATE}

While the validity of these settlements has been debated in courts in recent years, the current debate was brought to the attention of the public - and the legislature - by the much-publicized agreements attempted by pharmaceutical giant Bristol-Myers Squibb ("BMS"). Canadian generic manufacturer, Apotex, recently introduced a generic version of BMS's cash cow, Plavix, which prevents blood clots and reduces the risk of heart attack and stroke. Plavix, "[w]ith sales of almost $\$ 13$ million a day. . . and growing . . . is BMS's most important drug by a long way." 53 In an attempt to keep Apotex from cutting into Plavix's huge market share, BMS's holding company, Sanofi, attempted to settle with Apotex twice, in hopes of keeping Apotex's generic version off the market. ${ }^{54}$ Both settlements involved reverse payments to Apotex, in return for delayed entry of Apotex's version. The attorney general, however, refused to approve either settlement, finding that the "states object to and will not approve the Settlement Agreement." 55

After the attorney general's statement, the BMS litigation focused on the validity of the Plavix patent itself, culminating in a decision by the District Court that the Plavix patent was indeed valid. ${ }^{56}$ Although the BMS patent set-

49. ANGELL, supra note 2 , at 174.

50. Stephen Foley, Established Patents Threatened by Aggressive Generic Drug Firms, INDEPENDENT (U.K.), Aug. 22, 2006, at 38.

51. Under Attack: Drug Patents, The ECONOMIST (U.K), Sept. 9, 2006, at 94.

52. Foley, supra note 50.

53. Id.

54. Sanofi-Synthelabo v. Apotex, Inc., 488 F. Supp. 2d 317, 323-24 (S.D.N.Y), aff'd, 470

F.3d 1368 (2nd Cir. 2006), rehearing denied (Jan. 19, 2007).

55. Id. at 324 .

56. Sanofi-Synthelabo v. Apotex, Inc. 492 F. Supp. 2d 353, 397-98 (S.D.N.Y. 2007). 
tlement issue has effectively been dropped in the legal sphere due to the fact that neither settlement was approved, the fiasco caught both national and international attention, especially after BMS Chief Executive Officer Peter Dolan was dismissed by the company's Board of Directors, in part for his role in the ruined settlements. ${ }^{57}$

With no litigation on BMS's settlement agreement, the current debate has centered around three main settlements between brand name companies and their generic challengers: Schering's settlement with generic firms Upsher and ESI, Zeneca's settlement with generic manufacturer Barr, and Bayer's settlement with Barr.

\section{A. Schering-Plough: Patent Settlement Agreements with Upsher and ESI}

After generic manufacturers Upsher-Smith Laboratories and ESI Lederle, Inc. ("ESI") sought approval to market generic versions of Schering's high blood pressure medicine K-Dur 20, Schering entered into settlement agreements with both companies. Under its agreement with Upsher, the earliest entry date for Upsher's generic version was set for September 1, 2001, five years before the K-Dur 20 patent would expire. ${ }^{58}$ The settlement also included a three-part licensing deal for Schering to market other Upsher products, calling for Schering to pay sixty million dollars in royalty fees, ten million in milestone royalty payments, and a ten to fifteen percent royalty on sales. ${ }^{59}$ Knowing that ESI would be allowed to market its own version of K-Dur 20 once Upsher's 180-day period of market exclusivity ended, Schering attempted to settle with ESI as well. The ESI settlement allowed ESI's generic to enter the market on January 1, 2004, a full two and a half years before the expiration of the K-Dur twenty patent. ${ }^{60}$ In addition, Schering agreed to pay ESI ten million dollars, contingent on ESI gaining FDA approval by a certain date. ${ }^{61}$

After announcement of the settlement agreements, the FTC filed administrative complaints against all three companies, alleging illegal agreements in restraint of trade. ${ }^{62}$ The Eleventh Circuit found both agreements to be valid stating:

Given the costs of lawsuits to the parties, the public problems associated with overcrowded court dockets, and the correlative public and private benefits of settlements, we fear and reject a rule of law that would auto-

57. See Stephanie Saul, Drug Maker Fires Chief of 5 Years, N.Y. TiMEs, Sept. 13, 2006, at $\mathrm{C} 1$.

58. Schering-Plough Corp. v. FTC, 402 F.3d 1056, 1059 (11th Cir. 2005), cert. denied, 126 S.Ct. 2929 (U.S. June 16, 2006).

59. Id. at 1060 .

60. Id.

61. Id. at $1060-61$.

62. Id. at 1061 . 
matically invalidate any agreement where a patentholding pharmaceutical manufacturer settles an infringement case by negotiating the generic's entry date, and, in an ancillary transaction, pays for other products licensed by the generic. ${ }^{63}$

The Schering case was the first in this line of cases to be brought before the Supreme Court, in June, 2006. ${ }^{64}$ Despite the controversy, the Court denied certiorari, signaling its reluctance to involve itself in the issue at this time, and leaving the door open for Congress to resolve the issue of the validity of patent settlement agreements on its own. ${ }^{65}$

\section{B. Zeneca: Patent Settlement Agreement with Barr}

In 1985, generic pharmaceutical manufacturer Barr requested FDA approval to market a generic version of Zeneca's (now AstraZeneca) premier cancer drug, tamoxifen. ${ }^{66}$ After a district court found the tamoxifen patent invalid, and while appeal was pending, the two companies reached a settlement. ${ }^{67}$ Under the agreement, Barr agreed to change its ANDA paragraph IV certification to a paragraph III certification, pushing back market entry of its own version of the drug until 2002, after the initial patent had expired. ${ }^{68}$ In addition, Zeneca agreed to pay Barr twenty-one million dollars and awarded Barr a nonexclusive license to sell tamoxifen in the United States under Barr's name. ${ }^{69}$ Zeneca also paid Barr's raw material supplier $\$ 9.5$ million up front, plus an additional $\$ 35.9$ million over ten years. ${ }^{70}$

Years later, while distribution of tamoxifen was being litigated in courts across the country, a class action suit was filed against Zeneca and Barr to challenge the settlement agreement. ${ }^{71}$ In 2003, the Judicial Panel on Multidistrict Litigation for the Eastern District of New York found the settlement agreement valid and not a violation of the Sherman Act. ${ }^{72}$ In August 2006, the Second Circuit affirmed, finding that the agreement "did not unlawfully extend the

63. Id. at 1076 .

64. FTC v. Schering-Plough Corp., 126 S.Ct. 2929 (U.S. June 16, 2006).

65. Id.

66. Joblove v. Barr Labs, Inc. (In re Tamoxifen Citrate Antitrust Litig.), 466 F.3d 187, 193 (2d Cir. 2006), cert. denied, 127 S.Ct. 3001 (2007).

67. Id.

68. Id. at 193-94.

69. Id. at 193.

70. Id. at $193-94$.

71. Id. at 196.

72. Joblove v. Barr Labs., Inc. (In re Tamoxifen Citrate Antitrust Litig.), 277 F.Supp.

2d 121 (E.D.N.Y. 2003), aff'd, 466 F.3d 187, 196 (2d Cir. 2006). 
reach of Zeneca's tamoxifen patent."73 The Supreme Court denied certiorari in the case in June $2007 .^{74}$

\section{Bayer: Patent Settlement Agreement with Barr}

In 1997, generic manufacturer Barr again settled a patent infringement claim, this time with Bayer, manufacturer of the antibiotic Ciprofloxacin ("Cipro"). ${ }^{75}$ Under the terms of the settlement, Bayer paid Barr \$49.1 million in exchange for Barr's agreement to amend its ANDA to a paragraph III certification, thereby allowing market entry of Barr's generic version only after the expiration of the Cipro patent. ${ }^{76}$ Barr retained the option to re-amend its filing to paragraph IV if the patent was found to be invalid or unenforceable. ${ }^{77}$ Soon after the settlement was made public, a class action suit was filed against Bayer and Barr by direct and indirect purchaser class plaintiffs, claiming the settlement violated state and federal antitrust laws. ${ }^{78}$ In 2005 , the district court found the agreements to be valid, stating:

[T] he first element antitrust plaintiffs must prove is that the challenged agreements had an actual adverse effect on competition in the relevant market. Here, plaintiffs have failed to demonstrate anti-competitive effects in the market for ciprofloxacin because, although the [a]greements undoubtedly restrained competition, they did not do so beyond the scope of the claims of the " 444 Patent. $^{\text {,79 }}$

It should also be noted that both the Cipro and the tamoxifen patents were held to be valid against subsequent challenges from generic manufactures who also filed Paragraph IV ANDAs. ${ }^{80}$ The Cipro patent alone was held valid in at least three subsequent suits, and a fourth challenger withdrew its Paragraph IV certification soon after the third challenger lost. ${ }^{81}$ Based on this subsequent history, it is unlikely that Barr's challenges to either patent would have succeeded, making it unlikely that Barr would have been successful in marketing

73. Joblove, 466 F.3d at 213.

74. Joblove v. Barr Labs., 127 S. Ct. 3001 (U.S. June 25, 2007).

75. In re Ciprofloxacin Hydrocloride Antitrust Litig., 363 F. Supp. 2d 514, 518-19

(E.D.N.Y. 2005).

76. Id. at 519.

77. Id.

78. Id. at 517 .

79. Id. at 548 .

80. Id. at 519-20; Joblove v. Barr Labs, Inc. (In re Tamoxifen Citrate Antitrust Litig.), 466

F.3d 187, 195 (2d Cir. 2006) cert. denied, 127 S. Ct. 3001 (2007).

81. In re Ciprofloxacin Hydrocloride Antitrust Litig., 363 F. Supp. $2 \mathrm{~d}$ at 519-20. 
its generic versions of Cipro or tamoxifen before the patents expired even in the absence of the settlements.

As suggested by the settlements highlighted above, the courts have been reluctant to find patent settlement agreements invalid as violations of antitrust laws. Their reluctance seems to stem from a wariness of per se rules, ${ }^{82}$ and an idea that such settlements cannot be anticompetitive when the generic entrant is not delayed past expiration of the pioneer patent. ${ }^{83}$ These two themes have been the touchstones of the courts' reasoning and are explored below.

\section{THE DETAILS OF THE DEBATE}

The BMS settlement debacle, in addition to a recent outcry from consumer groups fighting the rising cost of health care, has brought the validity of patent settlement agreements to Congress' attention. Congressional hearings beginning in the summer of 2006 have continued into the new legislative session, spurred by the introduction of at least one bill attempting to resolve the issue. $^{84}$ The hearings, as well as recent articles and court decisions, provide insight into the arguments made on both sides of the debate.

\section{A. The Arguments for Settlement: The Courts and the Industry}

As suggested above, the incentives for pharmaceutical manufacturers to settle patent infringement claims are high. As such, the pro-settlement side of the debate has been led largely by pharmaceutical companies specializing in the research and development of both brand name and generic drugs. As antitrust litigation in the area has suggested, however, the courts have generally taken a pro-settlement view as well. Their reasoning and the arguments of the pharmaceutical companies are explored below.

\section{The Courts' Reasoning: Consistently Upholding Settlement Agreements}

As suggested by the Schering, Zeneca, and Barr settlements, courts have been reluctant to find patent settlement agreements invalid or in violation of the Sherman Act. Together, the three cases illustrate an emphasis by the courts on three main arguments for allowing patent settlement agreements: (1) courts should encourage settlement of litigation; ${ }^{85}(2)$ the goal of patent law is not circumvented by allowing companies to enter into these settlements; ${ }^{86}$ and (3) the

82. Schering-Plough Corp. v. FTC, 402 F.3d 1056, 1076 (11th Cir. 2005), cert. denied, 126 S.Ct. 2929 (U.S. June 16, 2006).

83. Id. at 1064 .

84. Preserve Access to Affordable Generics Act, S. 3582, 109th Cong. (2006).

85. Joblove, 466 F.3d at 202; Schering-Plough Corp., 402 F.3d at 1072-73.

86. Joblove, 466 F.3d at 202; In re Ciprofloxacin Hydrocloride Antitrust Litig., 363 F. Supp. $2 \mathrm{~d}$ at 524. 
existence of reverse payments does not render the settlement agreement invalid. $^{87}$

The Tamoxifen court clearly emphasized the benefits of encouraging settlement over litigation. The court seemed to equate encouragement of settlement with a kind of duty, stating that "[c]ourts are bound to encourage' the settlement of litigation." $" 88$ The court found that, when a legitimate patent conflict arises, such settlements are "'not precluded by the [Sherman] Act,' although such a settlement may ultimately have an adverse effect on competition." courages litigation participants to settle and that the right of settlement is not prohibited even in antitrust cases. ${ }^{90}$ The Eleventh Circuit mirrored this sentiment in Schering-Plough, stating that patent owners should not be disallowed the right of settlement, which is available to all other litigants, simply due to their status as patent holders. ${ }^{91}$

The courts also seem to agree that the "ultimate goal of stimulating competition and innovation" is not circumvented by allowing companies to enter into patent settlement agreements. ${ }^{92}$ In fact, the Second Circuit specifically argued against a per se rule prohibiting such settlements, stating, "the increased number of continuing lawsuits that would result would heighten the uncertainty surrounding patents and might delay innovation." 93 The court argued that patent settlements "promote efficiencies, resolving disputes that might otherwise block or delay the market entry of valuable inventions." "The district court hearing the Cipro case also emphasized that patent settlement agreements do not contradict the goals of patent law, stating that any anticompetitive effects cannot be redressed by antitrust law when the effects do not extend past expiration of the pioneer patent. ${ }^{95}$ The Second Circuit summarized this point, saying, "the patent holder is seeking to arrive at a settlement in order to protect that to which it is presumably entitled: a lawful monopoly over the manufacture and distribution of the patented product." tecting what it already legally owns, the court argues, such a settlement should be valid. ${ }^{97}$

87. Joblove, 466 F.3d at 206-7; Schering-Plough Corp., 402 F.3d at 1072.

88. Joblove, 466 F.3d at 202 (quoting Gamabale v. Deutsche Bank AG, 377 F.3d 133, 143 (2d Cir. 2004)) (emphasis added).

89. Id. (quoting Standard Oil Co. v. United States, 283 U.S. 163, 171 (1931)).

90. Id. at 205.

91. Schering-Plough Corp., 402 F.3d at 1072.

92. Joblove, 466 F.3d at 201.

93. Id. at 203.

94. Id. (quoting Joseph F. Brodley \& Maureen A. O'Rourke, Preliminary Views: Patent Settlement Agreements, ANTITRUST, Summer 2002, at 53).

95. In re Ciprofloxacin Hydrocloride Antitrust Litig., 363 F. Supp. 2d 514, 523-24

(E.D.N.Y. 2005).

96. Joblove, 466 F.3d at 208-9.

97. Id. 
Both the Second and Eleventh Circuits agree that the existence of reverse payments does not render the settlement agreement invalid. ${ }^{98}$ In Tamoxifen, the court asserted that the simple existence of reverse payments, without more, would not create a Sherman Act violation. ${ }^{99}$ The court even suggested that such a ban on reverse payments may be anticompetitive by reducing settlement options in patent cases and thereby reducing incentives to challenge patents altogether. ${ }^{100}$ The Eleventh Circuit added in Schering that the existence or size of a reverse payment should not dictate a decision, as " "even a patentee confident in the validity of its patent might pay a potential infringer a substantial sum in settlement.",101

In sum, the courts have repeatedly ruled against a strict prohibition on patent settlement agreements, choosing instead to encourage settlement, and promote efficiency, innovation, and flexibility in litigation. The courts seem to be in agreement on the issue, with arguments of one court often mirroring the arguments of other courts. Their focus on innovation, and the fear that prohibiting patent settlement agreements may impede innovation and investment, is echoed by the pharmaceutical industry itself.

\section{The Pharmaceutical Industry: Protecting Investments Through Settle- ment}

Until recently, PhRMA had been oddly quiet on the issue of patent settlement agreements, for the most part allowing the debate to take place only in the courtroom. Congressional testimony on the issue in January, 2007, featured some of the biggest players in the debate, including PhRMA CEO Billy Tauzin. Tauzin is a former U.S. Representative (R-LA) who chaired the House Energy and Commerce Committee, which regulates the pharmaceutical industry, until his retirement from the House in December, 2004. ${ }^{102}$ His switch from public sector regulator of the industry to pharmaceutical CEO in the private arena drew caustic criticism from some congressional democrats. ${ }^{103}$

Despite the controversy surrounding his former affiliation with the House, Tauzin has proven to be a powerful lobbyist for the pharmaceutical industry. In his testimony before the Senate Committee on the Judiciary, Tauzin touted the importance of patent protection for innovation, stating, "[p]atents provide the minimum degree of assurance for investors to risk the capital necessary to fund the pharmaceutical discovery process despite the uncertain chances of produc-

98. Id. at 206; Schering-Plough Corp. v. FTC, 402 F.3d 1056, 1075 (11th Cir. 2005), cert. denied, 126 S.Ct. 2929 (U.S. June 16, 2006).

99. Joblove, 466 F.3d at 206.

100. Id.

101. Schering-Plough Corp., 402 F.3d at 1075 (quoting Valley Drug v. Geneva Pharm., Inc., 344 F.3d 1294, 1310 (11th Cir. 2003)).

102. William M. Welch, Tauzin Switches Sides from Drug Industry Overseer to Lobbyist, USA TODAY, Dec. 16, 2004, at 4b.

103. Id. 
ing a commercially viable product." 104 He argued that a prohibition on settlements would force both brand name and generic manufacturers to spend large amounts of time and money pursuing endless litigation, which might decrease costs allotted for research and development. ${ }^{105}$ Further, he warned that those additional costs could be passed to consumers. ${ }^{106}$

In addition to threatening innovation, Tauzin warned that such prohibitions might also threaten generic drug development by reducing the incentive for generic manufacturers to challenge patents. ${ }^{107}$ With fewer options for ending litigation, there are fewer incentives to enter into litigation in the first place. In addition, Tauzin argued, the licensing rights often exchanged in patent settlement agreements often lead to greater competition and flexibility in the market, giving physicians and consumers more choices when choosing pharmaceutical treatments. ${ }^{108}$ Tauzin's business flexibility argument has been echoed by the media, as demonstrated by a September, 2006, Economist article which stated, "[T] he costs and legal uncertainty associated with patent trials are simply too great." 109

Tauzin is not the only supporter in the pharmaceutical industry's camp. Miles White, PhRMA member and chairman and CEO of pharmaceutical manufacturer Abbott Laboratories, recently published an article in The Financial Times on the subject of patents. ${ }^{110}$ White's argument emphasized two important benefits of patent settlement agreements: innovation and business efficiency.

White argued that patent protection, in all forms, is essential for pharmaceutical companies to continue to create innovative products, arguing that intellectual property protection has given rise to innovation and has even made innovation possible. ${ }^{111}$ Recognizing the huge investment required to produce even one viable drug, White said, "genius alone is not enough."112 He argued that companies need the possibility for a return on investment in order to make any investment at all profitable or even possible. ${ }^{113}$ White also argued that new medications could be created only through continued innovation, and that con-

104. Paying Off Generics to Prevent Competition with Brand Name Drugs: Should It Be Prohibited?: Hearing Before the S. Comm. on the Judiciary, 110th Cong. (January 17, 2007) [hereinafter 2007 Hearings], http://judiciary.senate.gov/hearing.cfm?id=2472 (statement of Billy Tauzin, CEO, PhRMA) (last visited Apr. 9, 2008).

105. Id.

106. Id.

107. Id.

108. Id.

109. Under Attack: Drug Patents, supra note 51.

110. Miles White, Drug Patents Are Good for Our Health, Financial Times (Asia), Nov. 30, 2005, at 15 .

111. Id.

112. Id.

113. Id. 
tinued innovation must be encouraged and protected, even through the use of patent settlement agreements. ${ }^{114}$

Not surprisingly, the arguments of the brand name manufacturers - that innovation requires protection and that settlement agreements provide business efficiency for the industry - are mirrored by their generic counterparts. In addition to these arguments, spokespeople for the generic pharmaceutical industry have advanced some of their own theories.

\section{The View of the Generic Manufacturers: A Good Business Decision}

$\mathrm{PhRMA}$ and brand name manufacturers are not the only members of the pharmaceutical industry to support patent settlement agreements. Indeed, generic manufacturers often gain as much, if not more, from these agreements. As Bruce Downey, Chairman and CEO of Barr Pharmaceuticals, suggested in his congressional testimony, patent settlement agreements provide the "sole means by which the public can be guaranteed generic access prior to patent expiration." 115 For instance, in both Cipro and Tamoxifen, at least three subsequent challengers lost their infringement cases against the pioneer manufacturer when the courts found the patents to be valid. ${ }^{116}$ As such, it is unlikely that Barr's generic versions would have entered the market before expiration of the pioneer patents even if no settlements had been reached. Citing the Cipro and Tamoxifen cases specifically as examples, Downey explained that "Barr[ ][comma omitted] was able to settle our litigation ... and secure early generic entry when four subsequent challengers all lost their cases. ... In short, these settlements all provided value to the consumer that would not have been achieved if the generics had proceeded to litigate and lose."117 Downey explained that, in essence, these settlements provided consumers with a generic version much earlier than would have been otherwise possible. ${ }^{118}$ Without these settlements, which allowed market entry immediately upon expiration of the pioneer patents, Barr would have been forced to wait until after expiration to even begin the approval process and may even have been forced to wait out another generic manufacturer's 180 -day exclusivity period.

While the settlements may have allowed earlier entry in these specific situations, evidence presented by the FTC suggests that Barr may be in the minority. According to an FTC study, generics actually prevailed in seventy-three

114. Id.

115. 2007 Hearings, supra note 104 (statement of Bruce L. Downey, Chairman \& CEO, Barr Pharm., Inc.).

116. In re Ciprofloxacin Hydrocloride Antitrust Litig., 363 F. Supp. 2d 514, 519-20 (E.D.N.Y. 2005); Joblove v. Barr Labs, Inc. (In re Tamoxifen Citrate Antitrust Litig.), 466 F.3d 187, 195 (2d Cir. 2006) cert. denied, 127 S. Ct. 3001 (2007).

117. 2007 Hearings, supra note 104 (statement of Bruce L. Downey, Chairman \& CEO, Barr Pharm., Inc.).

118. Id. 
percent of Paragraph IV infringement suits filed between 1992 and $2000 .{ }^{119}$ In addition, according to congressional testimony in 2002, consumers saved an estimated nine billion dollars after only four successful challenges by generic manufacturers. ${ }^{120}$

Downey also contradicted arguments that, absent reverse payments, patent settlement agreements would include provisions for the generic drug to enter the market much earlier. He stated, "a monetary settlement [cannot] always be converted into a time period of early entry...." ${ }^{21} \mathrm{He}$ also suggested other considerations, such as differing perspectives on the risks of litigation and changing future market conditions, might often impede settlement. ${ }^{122}$ In such cases where settlement cannot be achieved otherwise, monetary payments may help pave the way for generic drugs to enter the market before expiration of the patent, as in the Schering case. ${ }^{123}$

Like the courts, the pharmaceutical industry has focused its arguments on protection of innovation and the right to settlement. Despite the persuasiveness of these arguments, the FTC and other consumer groups are not convinced, and have criticized such settlements both in the courts and before Congress.

\section{B. The Arguments Against Patent Settlement Agreements: The FTC and the Consumer}

The other side of the debate - that which suggests patent settlement agreements are anticompetitive and harmful to consumers-is presented principally by the FTC, which has repeatedly taken the issue to the courts, only to lose. Consumer groups, and even some lawyers, have added their concerns to those of the FTC. The concerns revolve around cost to consumers and the major decrease seen in the price of brand name drugs when generics enter the market.

\section{The FTC: Protecting the Consumer}

In July, 2006, FTC Commissioner Jon Leibowitz testified before Congress on the subject of generic pharmaceutical drugs and the barriers to market entry they often face. Much of his testimony focused on patent settlement agree-

119. Id. (prepared statement of the Fed. Trade Comm'n, presented by Jon Leibowitz, Comm'r).

120. Jaeger, supra note 2, at 12 (computing consumer savings based on generic versions of Prozac ( $\$ 2.5$ billion), Zantac ( $\$ 2.45$ billion), Taxol ( $\$ 3.5$ billion), Relafen ( $\$ 109$ million), and Plantinol ( $\$ 1$ billion)).

121. 2007 Hearings, supra note 104 (statement of Bruce L. Downey, Chairman \& CEO, Barr Pharm., Inc.).

122. Id.

123. Schering-Plough Corp. v. FTC, 402 F.3d 1056, 1059-60 (11th Cir. 2005), cert. denied, 126 S.Ct. 2929 (U.S. June 16, 2006). 
ments and the reasons behind the FTC's continuing attempts to strike down such settlements.

In his testimony, Leibowitz emphasized that generic drugs are an indispensable part of lowering prescription drug costs to consumers. ${ }^{124}$ Specifically, Leibowitz said, generic drugs saved consumers $\$ 8-10$ billion in 1994 alone. $^{125}$ Leibowitz argued that since patent settlement agreements often include a deferral of market entry of generic drugs these settlements ultimately cost consumers. ${ }^{126}$

Due to these perceived high costs, Leibowitz argued for Congress to consider a ban on all patent settlements which include reverse, or exclusionary, payments. While he recognized the business benefits of such settlements, Leibowitz argued, "consumers lose the possibility of an earlier generic entry, either because the generic company would have prevailed in the [infringement] lawsuit or the parties would have negotiated a settlement with an earlier entry date but no payment."127 Liebowitz specifically criticized the courts' position on the issue, arguing that the Schering and Tamoxifen decisions will decrease generic competition, creating further costs to consumers, insurers, and employers. ${ }^{128}$

In addition, Leibowitz argued that, despite the remedy to the bottleneck problem contained in the Medicare Act, recent court decisions have effectively eliminated the Medicare Act's solution. ${ }^{129}$ Under this Act, subsequent generic filers may remove the initial bottleneck caused by the first filer's 180-day exclusivity period by obtaining a court decision finding the pioneer patent invalid or not infringed. ${ }^{130}$ The District of Columbia Circuit, however, recently found that the FTC need not treat "dismissal of a declaratory judgment action as a court decision sufficient to trigger the exclusivity period," effectively blocking subsequent filers from obtaining any such judgment in absence of an infringement suit by the pioneer manufacturer, and leaving subsequent filers with no mechanism to relieve the bottleneck. ${ }^{131}$ After the court's decision, any brand name manufacturer who wishes to keep the bottleneck in place simply has to refrain from suing subsequent filers. In his testimony, Liebowitz purposed a simple fix to the bottleneck problem, asking Congress to "clarify that dismissal of an action brought by a generic applicant seeking a declaratory judgment con-

124. Barriers to Generic Entry: Prepared Statement of the Federal Trade Commission Before the S. Spec. Comm. on Aging, 109th Cong. 1 (July 20, 2006) [hereinafter 2006 Hearings], available at $\mathrm{http} / / / \mathrm{www} . \mathrm{ftc} . g o v / 0 \mathrm{~s} / 2006 / 07 / \mathrm{P} 052103 \mathrm{BarrierstoGenericEntryTesti}$ monySenate07202006.pdf (statement of Jon Leibowitz, Comm'r, Fed. Trade Comm'n.

125. Id. at 2. (citing Cong. Budget Office, How Increased Competition from Generic Drugs Has Affected Prices and Returns in the Pharmaceutical Industry (July 1998)).

126. Id. at 12.

127. Id.

128. Id. at 16-17, 19.

129. Id. at 20 .

130. Id. at 21 .

131. Teva Pharm. USA, Inc. v. FDA, 441 F.3d 1 (D.C. Cir. 2006). 
stitutes a forfeiture event for the 180-day exclusivity period."132 In other words, any dismissal of a declaratory judgment would clear the bottleneck, allowing subsequent generic filers to begin marketing their own versions of the pioneer drug.

Leibowitz presented testimony to Congress on the subject again in January, 2007, this time before the Senate Committee on the Judiciary. ${ }^{133}$ Leibowitz's comments echoed those made in his July, 2006, testimony and he again asked Congress for a legislative remedy. ${ }^{134}$

\section{Consumer Groups and Other Interested Parties}

Some consumer groups have added their concerns to those expressed by the FTC. In particular, Consumers Union (the "Union"), the nonprofit publisher of Consumer Reports, has joined the fray with congressional testimony that mirrors the arguments of Leibowitz. ${ }^{135}$ Union project director, Michael Wroblewski, specifically stated that the Union supports congressional action on the issue, arguing that patent settlement agreements "jeopardize the health of millions of Americans who have difficulty obtaining safe and effective medicines at affordable prices." 136 While recognizing that economics offer powerful incentives for companies to enter such settlements, Wroblewski echoed Leibowitz's argument that settlements decrease generic competition because, in the absence of reverse payments, generic drugs may have been able to enter the market earlier, through different settlement options or the invalidation of the pioneer patent. ${ }^{137}$ Wroblewski also argued that such patents are contrary to the purpose of the Hatch-Waxman Amendments, relying on statements from Senator Orrin Hatch (R-UT), one of the sponsors of the Act. ${ }^{138}$ During recent debates, Senator Hatch said, "[w]e did not wish to encourage situations where payments were made to generic firms not to sell generic drugs and not to allow multi-source competition."139

Additionally, Wroblewski argued that the Second and Eleventh Circuits relied on false assumptions in the Schering and Tamoxifen cases. ${ }^{140} \mathrm{He}$ argued that, contrary to the courts' view, settlements could be found illegal without requiring that the pioneer patent be invalid. ${ }^{141}$ In addition, he argued that poli-

132. 2006 Hearings, supra note 124, at 23 (statement of Jon Leibowitz, Comm'r, Fed. Trade Comm'n).

133. 2007 Hearings, supra note 104 (prepared statement of Jon Leibowitz, Comm'r, Fed. Trade Comm'n).

134. Id.

135. Id. (statement of Michael Wroblewski, Project Dir., Consumer Educ. \& Outreach, Consumers Union).

136. Id.

137. Id.

138. Id.

139. Id. (quoting Senator Orrin Hatch).

140. Id.

141. Id. 
cy which encourages settlement should not outweigh policy which encourages generic entry, especially when such policy has been codified by Congress. ${ }^{142}$ Wroblewski, speaking on behalf of the Union, also called for Congress to remove the 180 -bottleneck problem, as suggested by Liebowitz. ${ }^{143}$

\section{MAKING THE CALL: THE BEST OPTION FOR CONGRESS}

In the absence of a Supreme Court decision, Congress is being called on to enter the fray. With arguments on both sides, legislators are facing a difficult decision: Address the issue of patent settlement agreement validity, or simply leave the issue to the courts to decide. If Congress takes the former route, it faces another important decision: whether or not such settlements should be valid in all cases or only in limited circumstances or if patent settlement agreements should be banned across the board.

\section{A. The Call for Congressional Action}

Congressional action on the issue of patent settlement agreements is being called for on all fronts. The Supreme Court's denial of certiorari in the Schering case left the FTC, and the consumers it seeks to protect, without remedy in the courts. The denial may be an indication that the Court sees no need to involve itself in the debate, or that it feels that district and circuit courts have shown themselves competent to rule on these issues. On the other hand, the Supreme Court's denial may also be seen as an indication that the Court is deferring to the legislature to make any changes in the law-an indirect suggestion that Congress rule on the issue.

The lower courts are also calling on Congress for help. For example, the district court in Cipro specifically stated that any readjustments in patent law should be addressed by Congress, rather than the courts. ${ }^{144}$

As Leibowitz's congressional testimony demonstrates, the FTC is also calling for congressional action on the issue. At a 2006 forum, Leibowitz recognized that Congress had chosen to intervene in the issue in the past, and suggested that it do so again. ${ }^{145}$ More recently, in his January, 2007, testimony, Leibowitz gave specific reasons for a need for congressional guidance, calling patent settlement agreements "a matter of pressing concern."146 He cited the

142. Id.

143. Id.

144. In re Ciprofloxacin Hydrocloride Antitrust Litig., 363 F. Supp. 2d 514, 548 (E.D.N.Y. 2005).

145. Jon Leibowitz, Comm'r, Fed. Trade Comm'n, Address at the Second Annual InHouse Counsel's Forum on Pharmaceutical Antitrust: Exclusion Payments to Settle Pharmaceutical Patent Cases: They're B-a-a-a-ck! 9 (April 24, 2006), available at http://www.ftc. gov/speeches/leibowitz/060424PharmaSpeechACI.pdf.

146. 2007 Hearings, supra note 104 (prepared statement of Jon Leibowitz, Comm'r, Fed. Trade Comm'n). 
need for a swift remedy, and stated that, since this has been treated as a policy issue, Congress should set guidelines based on its authority to delineate policy. ${ }^{147}$ Repeating a statement made in his July, 2006, testimony, the Commissioner made the FTC's support of legislation very clear, stating, "[a] law must be broad enough to prevent evasion or other anticompetitive practices that could render the legislation ineffective, but it should avoid unwarranted deterrence to settlement of suits." 148

In the past five years, almost half of the country's most-prescribed pharmaceuticals have faced generic competition for the first time. ${ }^{149}$ By 2012, twenty blockbuster drugs will face patent expiration or will lose market exclusivity. ${ }^{150}$ The implications for pharmaceutical company profits, and consumer savings, are staggering. Congress must address this issue now, before more patent settlement agreements are reached and challenged, and subsequently tied up in years of endless litigation.

\section{B. Congress' Options: Codification, Legislation, and Limitation}

Given the clear call for congressional intervention, it is likely that Congress will respond in the upcoming legislative sessions. Hearings on the subject have already begun, leaving only the question of what action Congress might take.

Congress' first option, of course, is to do nothing - to simply ignore the debate and allow the courts to continue to adjudicate challenges to settlement agreements as they have been doing. This is the option suggested by the pharmaceutical industry. In his January, 2007, congressional testimony, Tauzin suggested that a legislative remedy would be inappropriate and that "enforcement agencies and courts should continue to evaluate patent settlements on a case-by-case basis." "151 Tauzin argued that courts are in the best position to decide issues of harm to consumers, and that FTC challenges to anticompetitive settlements keep the industry from abusing the settlement option. ${ }^{152}$ However, Congress has shown no intention of leaving this issue to the courts. The Medicare Act and recent hearings on the subject both suggest that this is an area of continuing concern for Congress, and indicate that Congress will not likely choose to remain silent on the issue.

Another option available to Congress is to limit patent settlement agreements, making them valid in only certain, narrow situations. However, the current limitations imposed by the courts - that the infringement claim be "neither

147. Id.

148. Id.; see also 2006 Hearings, supra note 124, at 20 (statement of Jon Leibowitz, Comm'r, Fed. Trade Comm'n).

149. Jaeger, supra note 2, at 13.

150. Id.

151. 2007 Hearings, supra note 104 (statement of Billy Tauzin, CEO, PhRMA).

152. Id. 
a sham nor otherwise baseless"153 and that the settlement does not "[constrain] competition beyond the scope of the patent" ${ }^{\prime 154}$-are already sufficiently narrow to allow settlements only when the protection provided by patent law is not being contravened. It is likely that any further limitations would effectively prohibit settlement agreements.

Congress could also choose to codify the courts' decisions, in order to avoid FTC challenges and the years of litigation they create, accepting the courts' arguments that such agreements do not constitute antitrust violations. If Congress chooses this option, it is anticipated that the current limitations would be codified, creating a legislative requirement that settlement be valid only as long as the infringement claim is not a sham and the settlement does not defer market entry past the expiration of the patent. This choice could also include the FTC's suggestion of clarification for the 180-day exclusionary period in order to prevent further bottleneck problems.

Finally, Congress could choose to ban patent settlement agreements altogether. In fact, this option has already been given some congressional consideration. In January, 2007, Senator Herb Kohl (D-WI) introduced the Preserve Access to Affordable Generics Act. ${ }^{155}$ The Act prohibits any agreements between brand name manufacturers and generic manufacturers when, "(A) an ANDA filer receives anything of value; and (B) the ANDA filer agrees not to research, develop, manufacture, market, or sell the ANDA product for any period of time." generic manufacturer receives compensation in return for a delay in market entry. The bill is still in committee and is unlikely to come to a vote in the near future; however, it has gained support at least from the FTC. In his January, 2007 , testimony Commissioner Leibowitz specifically supported the bill, stating, "The Commission strongly supports the intent behind the bipartisan legislation introduced by Senators Kohl, Leahy, Grassley, and Schumer."157

The FTC is not alone in its support of such a bright-line rule. Merril Hirsh, partner in a large Washington, D.C. law firm which represents clients on both sides of the issue, testified before Congress that a bright-line rule "is the simplest, most efficient and fairest solution to the patent lawsuit issue."158 Hirsh argued that such a rule is the only way to promote the purpose of the

153. Joblove v. Barr Labs, Inc. (In re Tamoxifen Citrate Antitrust Litig.), 466 F.3d 187, 208 (2d Cir. 2006) cert. denied, 127 S. Ct. 3001 (2007).

154. In re Ciprofloxacin Hydrocloride Antitrust Litig., 363 F. Supp. 2d 514, 540 (E.D.N.Y. 2005).

155. Preserve Access to Affordable Generics Act, S. 316, 110th Cong. (2007) (cosponsored by Senators Brown (D-OH), Durbin (D-IL), Feingold (D-WI), Grassley (R-IA), Johnson (D-SD), Kennedy (D-MA), Leahy (D-VT), Obama (D-IL) and Schumer (D-NY)). An earlier version of the bill, introduced to the 109th Congress, died in committee. Preserve Access to Affordable Generics Act, S. 3582, 109th Cong. (2006).

156. S. 316.

157. 2007 Hearings, supra note 104 (prepared statement of Jon Leibowitz, Comm'r, Fed. Trade Comm'n).

158. Id. (statement of Merril Hirsch, partner, Ross, Dixon \& Bell, LLP). 
Hatch-Waxman Act. She argued that without reverse payments on the table, generic companies will challenge patents only when they genuinely believe they will be successful, giving both companies incentive to settle at arms-length. ${ }^{159}$ A bar against reverse payments, she argued, will encourage efficient litigation, by decreasing the incentive of generic companies to challenge all pioneer patents. ${ }^{160}$ Finally, Hirsch argues that reverse payments are anticompetitive because they may be used by brand name pharmaceutical companies to delay all generic entry, not just the first or second competitors. ${ }^{161}$

Even some outside the judicial and legislative system support a bright-line rule against patent settlement agreements which include reverse payments. A recent New York Times editorial on the subject called for a "bright-line prohibition against making any payments to delay introduction of a generic drug."162 The editorial suggested that the industry needs a clear standard that would allow consumers to benefit from generic competition. ${ }^{163}$

A bright-line rule, however, is opposed by both the courts and the pharmaceutical industry. The courts suggest that such a rule would contravene both patent law and the right of parties to settle litigation outside of the courtroom. As the Second Circuit stated, "such a requirement would be contrary to wellestablished principles of law. . . . It is too late in the journey for us to alter course."164 Tauzin spoke out against such a prohibition as well, stating, "that kind of rule is overbroad and would chill all settlements-even those that allow generic entry before patent expiration or contain other provisions that facilitate the availability of products to help patients live longer, healthier lives." "165

\section{The Right Choice: Codification, with Limits}

Given the policy implications, as well as the implications for consumer costs, Congress must provide the industry, and the FTC, with an answer to this issue. Congress should choose to codify the courts' position, effectively prohibiting FTC intervention in any future settlements of this kind. As mentioned above, this codification would allow brand name and generic pharmaceutical manufacturers to enter into patent settlements agreements as long as (1) the infringement claim is "neither a sham nor otherwise baseless"166 and (2) the settlement does not "[constrain] competition beyond the scope of the patent.",167

159. Id.

160. $I d$.

161. Id.

162. Editorial, Return of the Drug Company Payoffs, N.Y. Times, Jan. 24, 2007, at A20.

163. Id.

164. Joblove v. Barr Labs, Inc. (In re Tamoxifen Citrate Antitrust Litig.), 466 F.3d 187, 212 (2d Cir. 2006) cert. denied, 127 S. Ct. 3001 (2007).

165. 2007 Hearings, supra note 104 (statement of Billy Tauzin, CEO, PhRMA).

166. Joblove, 466 F.3d at 208.

167. In re Ciprofloxacin Hydrocloride Antitrust Litig., 363 F. Supp. 2d 514, 540

(E.D.N.Y. 2005). 
As the courts have found, when these two criteria are satisfied, patent settlement agreements do not violate antitrust laws and should be valid.

First, limiting or prohibiting settlement agreements contradicts the basic legal theories that settlement is to be encouraged and that businesses are to have the ability to contract when there are no anticompetitive effects. As the courts have suggested, encouraging settlement is a tenet of the American legal system. The right to settle should not be precluded because a pharmaceutical patent exists. Indeed, owners of non-pharmaceutical patents still enjoy this right.

Further, patents themselves are anticompetitive, giving the holder a legal monopoly for a certain period of time. If pharmaceutical companies are awarded patents, they should be allowed the opportunity to protect those patents until expiration, or until the patent is found to be invalid. Only when the patent expires or is found invalid is the monopoly no longer legal. It is only at this point that anticompetitive effects are felt if generic companies continue to avoid market entry. Brand name and generic pharmaceutical companies should therefore be free to contract together until this point is reached.

Second, prohibition or further limitation of settlement agreements may cause a chilling effect on pharmaceutical innovation. While the benefits of generic drugs to consumers are not debated, a loss of innovation would be devastating to the American health care system. Costs of patent litigation and inability to protect patents through settlement may cause pharmaceutical companies to spend less on research and development, thereby decreasing the number of new drugs introduced to the market each year. If companies are denied opportunities to protect their innovation, they will have little incentive to engage in innovative activities. A decrease in innovation would likely result in the introduction of fewer pioneer drugs and, by implication, fewer and more costly generic drugs. Ultimately, consumers would be harmed by a decrease of innovative drugs, as many diseases and health issues may go un-researched and untreated.

In addition to threatening innovation, prohibiting patent settlement agreements may also delay the entry of some generic drugs past the point of delay agreed to by settlement. As suggested by the Barr examples, settlements occasionally invite generic drugs to the market even in situations where the pioneer drug is found to be valid by the courts. In addition, the Schering case demonstrates that some generic drugs will be given access to early market entry through settlement. Settlements often provide generic companies with licenses to market drugs to which they would not have had access otherwise. Thus, prohibiting settlements could remove these opportunities for generic manufacturers, thereby denying consumers access to cheaper versions of these drugs.

Third, prohibiting settlement could lead to further costs to consumers. The FTC's consumer-based arguments fail to consider the extra costs of litigation, which may be passed on to consumers by both brand name and generic manufacturers. Patent litigation often continues for years, costing each side millions of dollars. If settlement is no longer an option, litigation costs will 
continue to escalate. Eventually, parties to such litigation may be forced to pass these high costs on to consumers in the form of higher prescription drug prices.

Higher litigation costs may also leave pharmaceutical companies with fewer resources to spend on initiatives which seek to reduce prescription drug costs and increase access to prescription drugs - two initiatives which undoubtedly should be supported by the FTC and consumer groups. One such initiative is the Partnership for Prescription Assistance Program ("PPA"), founded in 2005. . $^{168}$ The program, sponsored by PhRMA members, joins health care providers, community groups, and patient advocacy groups to provide uninsured or underinsured patients access to patient assistance programs. ${ }^{169}$ By November, 2006, the PPA had served more than three million people. ${ }^{170}$ Such initiatives should be encouraged and could be compromised by increased litigation costs to pharmaceutical companies.

As such, a bright-line rule against reverse payments should be discouraged. Specifically, the Preserve Access to Affordable Generics Act should not be passed. Not only does the proposed Act prohibit reverse payments, it effectively prohibits all forms of compensation in cases where the generic agrees to a delayed entry date. ${ }^{171}$ Without the possibility of consideration, there will be little incentive for either side to settle. Especially given the high success rate of generic challenges, generic filers will be especially wary of any type of settlement. In most cases, the generic will be willing to attempt litigation and hope the pioneer patent will be found invalid or not infringed, allowing the generic to enter the market immediately. This unwillingness to settle will likely lead to greater litigation costs and may even reduce opportunities for generics to enter the market early or to gain licenses for other brand name drugs. In cases such as Cipro and Tamoxifen, where the patents were found to be valid, ${ }^{172}$ the generic may be excluded from the market, as there will be little incentive to settle with the pioneer patent holder. Indeed, in cases where the costs of litigating an ANDA suit outweigh the potential profits, generic filers may be further discouraged from challenging the pioneer patent if the possibility of settlement is foreclosed. Such a bright-line rule would be an "unwarranted deterrence to

168. Press Release, Partnership for Prescription Assistance, Unprecedented National Program to Help Millions of Uninsured Americans Get the Prescriptions Medicines They Need (Apr. 5, 2005), https://www.pparx.org/press_release.php?PHPSESSID=b30365ff079fe156d6f5 020a56dbaf74 (last visited Mar. 17, 2008).

169. Partnership for Prescription Assistance, Program OVerview, https://www. pparx.org/about.php (last visited Mar. 15, 2008).

170. Press Release, Partnership for Prescription Assistance, Three Million Americans Find Help Through Partnership for Prescription Assistance (Nov. 1, 2006), https://www.pparx.org/ ppa_milestone_3mil.php (last visited Mar. 17, 2008).

171. Preserve Access to Affordable Generics Act, S. 3582, 109th Cong. (2006).

172. In re Ciprofloxacin Hydrocloride Antitrust Litig., 363 F. Supp. 2d 514, 519-20 (E.D.N.Y. 2005); Joblove v. Barr Labs, Inc. (In re Tamoxifen Citrate Antitrust Litig.), 466 F.3d 187, 195 (2d Cir. 2006) cert. denied, 127 S. Ct. 3001 (2007). 
settlement of suits," exactly what the FTC Commissioner suggested should be avoided when creating legislation to address this issue. ${ }^{173}$

Simply removing the possibility of reverse payments will not ensure that brand name companies will settle with generic manufacturers for an earlier entry date. As mentioned, a prohibition on reverse payments may decrease incentive to settle at all. Even if reverse payments are disallowed, however, and companies do find reasons to settle, there is no guarantee that either settlement or settlement for earlier entry will be reached. Other market considerations may impede settlement in these cases.

Contrary to Hirsh's argument, ${ }^{174}$ even in the absence of such a ban on settlement compensation, patent settlement agreements involving reverse payments will not be available to every brand name manufacturer facing a generic challenger. From a business perspective, reverse payments are made when the amount of the payment is less than the amount of profits at risk if the generic manufacturer wins. This situation will often occur only with the first, and maybe the second, challenger. Business and market considerations will decrease the incentive to settle with each subsequent challenger until there is no incentive left at all. Once this point is reached, litigation will be the only option left to both companies.

Hirsh also argues that such a rule will encourage efficient litigation. ${ }^{175}$ It is unlikely, however, that generic manufacturers would re-evaluate which pioneer patents to challenge based on the absence of a possibility of receiving reverse payments. The success of most generic companies depends on challenging and winning patent infringement suits; thus many generics challenge any and all patents they deem to be profitable. This is unlikely to change, especially given the high success rate of such challenges.

Finally, as suggested by the FTC itself, bottleneck problems can be easily remedied by Congress without prohibiting or limiting the availability of settlement agreements. Congress should amend the Hatch-Waxman Act to clarify that a dismissal of a generic challenge to a pioneer patent would end the generic's 180-day exclusivity period. This simple amendment would end the bottleneck problem and allow other generic companies to subsequently enter the market, increasing generic competition while still protecting the original patent.

\section{CONCLUSION}

Congress should allow patent settlement agreements in situations where the patent infringement claim is valid and where the period of exclusivity is not extended past patent expiration. In the pharmaceutical industry, investment and

173. 2007 Hearings, supra note 104 (prepared statement of Jon Leibowitz, Comm'r, Fed. Trade Comm'n); see also 2006 Hearings, supra note 124 (statement of Jon Leibowitz, Comm'r, Fed. Trade Comm'n).

174. 2007 Hearings, supra note 104 (statement of Merril Hirsh, partner, Ross, Dixon \& Bell, L.L.P.).

175. Id. 
the possibility of recouping costs of those investments drive business plans for both brand name and generic manufacturers. Patent settlement agreements allow industry participants to end litigation efficiently and quickly, and provide business stability to the industry. This stability allows pioneer companies to invest in cutting edge research, which provides consumers with innovative drugs. Stability also helps generic manufacturers choose which drugs to target, allowing them to bring a greater variety of generic versions to consumers. Stability plays a critical role in keeping pharmaceutical costs from sky-rocketing and protects the consumer from those rising costs.

While consumer costs should always be a consideration for Congress, congressional action should be taken based on facts. Market issues and incentives must be a factor in considering the issue of patent settlement agreements. In this case, stability and innovation must be protected in order to continue the success of the pharmaceutical industry. 
, 